\title{
Legal Change and Class Interests: A Review Essay on Morton Horwitz's The Transformation of American Law
}

\author{
Charles J. McClain, Jr. $\dagger$
}

Legal history has traditionally been synonymous with the history of the Supreme Court and with the analysis of the great opinions of that tribunal. However, as Morton Horwitz points out in the introduction to his new book on the development of the American common law, The Transformation of American Law, 1780-1860:

[C]onstitutional cases are ... unrepresentative either as intellectual history or as examples of social control . . . .

[J]udicial promulgation and enforcement of common law rules constituted an infinitely more typical pattern of the use of law throughout most of the nineteenth century. By thus focusing on private law we can study the more regular mstances im which law, economy, and society imteracted. ${ }^{1}$

One of Professor Horwitz's primary objectives in this important and long-awaited work is, therefore, to make the technically difficult and soinetimes obscure subject of private law accessible to professional historians ${ }^{2}$ and others interested in the American past. In this, Horwitz succeeds remarkably well. Trained in the law as well as in pohtical science, he ranges with ease and faniharity over topics as diverse as the law of water rights, mercantile msurance, and negotiable instruments. He succeeds in making these relatively dense areas of the law understandable to the educated layman, at least to the layman who is not averse to reading a text patiently and perhaps more than once. This book is a prodigious work of scholarship ${ }^{3}$ that will likely have the

$\dagger$ Vice Chairman, Program in Jurisprudence and Social Policy, University of California, Berkeley. A.B. 1964, Xavier University; M.A. 1966, Columbia University; Ph.D. 1972, Stanford University; J.D. 1974, University of California, Hastings College of Law.

I wish to thank Dean Sanford Kadish and Professors Ronan Degnan, James Gordley, Sheldon Messinger, and Philip Selznick for reading and commenting on an earlier draft of this paper.

1. M. Horwitz, The Transformation of American Law, 1780-1860, at xii (1977).

2. Id. at xi.

3. The book was awarded the Bancroft Prize in American History, 1978. It represents the culmination of years of research, and one can only stand in awe of the eighty pages of detailed, narrative footnotes that accompany the 266-page text. 
effect of awakening many, historians and legal scholars alike, to the significance of hitherto neglected areas of American social history.

A far more important purpose of Professor Horwitz's book, however, is to advance a thesis concerning the animating forces behind the transmutations that occurred in the American common law during the period between the end of the Revolution and the beginning of the Civil War, a period that virtually all scholars agree was one of simgular change and ferment in the American legal system. Horwitz's thesis is that a deliberate choice was made durimg the early nineteenth century to promote economic growth through changes in the legal rather than the tax systein. In turn, this choice entailed the transformation of the American common law from a fundamentally anticommercial, antidevelopinental body of doctrine that was protective, paternalistic, and expressive of the moral sense of the community, into an essentially amoral system of rules that promoted economic growth at all costs, subsidized large enterprises at the expense of sinall, and destroyed old forins of wealth and property in favor of newer ones. These changes in the law were facilitated, Horwitz argues, by the American common law judges in response to the desires of conımercial interests and their allies in the legal profession. This bold and novel imterpretation gives an edge to Horwitz's presentation not often found in works of legal history. Nevertheless, the thesis that he advances does not seem to me to be adequately supported by the evidence offered. Before assaying the adequacy of the interpretation, however, I should like to consider Horwitz's account of the developments in the American common law from 1780 to 1860 . It is possible, I believe, to assess separatcly Horwitz's description of the changes that were taking place in American law and his interpretation of the causative factors that lay behind these changes.

Before particular areas of the substantive law could be transformed, Horwitz believes it was first necessary to discard the general view of law and of the function of law that prevailed in the United States in the eighteenth century and to develop a newer, more instrumental vision. In particular, it was necessary to ease the English common law off the pedestal which it occupied in prerevolutionary American legal thinking. "[T]he overwhelming fact about American law through inost of the eighteenth century," Horwitz notes, "is the extent to which lawyers believed that English authority settled virtually all questions for which there was no legislative rule." This was, of course, a natural consequence of the belief, firmly held by all colonial legal theorists, that the Enghish common law was declaratory of the law

4. M. HoRwIrz, supra note 1 , at 8 . 
of nature. As it was put by Josiah Quincy, common law rules were " founded in principles, that are permanent, uniform and universal." "5

Horwitz is most effective in docunenting how this jurisprudential view was gradually undermined in the last decades of the eighteenth and the first decades of the nineteenth centuries. Thus, as early as 1791, in Supreme Court Justice James Wilson's lectures on law, Horwitz finds a questioning of Blackstone's view that legal obligation derives from the common law's inherent rightness or justice. ${ }^{6}$ Furthermore, Horwitz sees in these lectures the articulation of the more modern notion that law is basically a reflection of the popular will and hence that legal obligation is the result of individual consent to be bound by the will of the majority. In short, this view constituted an adumbration of the positivist conception of law as sovereign command. ${ }^{7}$ The reasons for this newfound willingness to challenge the sanctity of the English common law were manifold, but it is likely that elnerging American nationahsm and anti-British feeling aided and abetted the trend. The trend is starkly illustrated in a series of marine insurance cases decided by American courts during England's wars with Napoleon. ${ }^{8}$ American judges had hittle difficulty in deciding that the opinions that issued from the English bench were not always founded on umiversal principles of justice. As one New York court noted, in a statement that would have been deemed heresy a scant few decades before, "There is not any uniform law by which these [English] courts govern themselves' . . . . 'They listen more to mstructions from the sovereign than to the injunctions of the law of nations." "9

If American judges in this era were demystifying the English common law, they were at the saine tinie, Horwitz argues, commg to take an entirely new, and much more activist, view of their own roles. Once it was accepted that courts did not exist simply to discover and declare eternal primciples of justice, the conclusion was inescapable that courts had the positive obligation to create law. Horwitz thus proposes that what seemed to the judges most likely to promote the best interests of the new American nation alone was the governing consideration in ju-

5. Id. at 7 (emphasis in original).

6. Id. at 18-19.

7. Id. For a different view of the common law tradition, suggesting that throughout the modern period, in both England and America, common law adjudication has been informed less by a belief in eternal principles and abstract ideals than by the learning that derives from the cumulative and diverse experience of doing justice in a particular society, see Selznick, The Ethos of American Law, in THE AMERICANS: 1976 (I. Kristol \& P. Weaver eds. 1976).

8. The cases all raised the question whether the insured parties had the right to collect from their insurers under pohcies that covered the seizure of neutral property by warring powers; the legal issue was whether United States courts needed to defer to the judgment of English admiralty courts that the property in question was nonneutral.

9. M. HoRwITZ, supra note 1 , at 27 . 
dicial legislation. A judge in one of the marine insurance cases illustrates this consideration: "[W]e are at liberty to adopt such a construction of the litigated contract as shall most subserve the solid interests of this growing country." 10 This highly activist view of the role of the judge was not easily reconciled with the prevailing theories of democracy and popular sovereignty. Judges answered charges of undemocratic action by explaining that they were not unilaterally making legislation, but mstead were taking notice of universally accepted usages and customs. Besides, the institution that incontestably was the purest repository of the democratic will, the legislature, could always overrule judge-made law; its failure to do so could be interpreted as implicit approval of court decisions. Horwitz concedes that there were those who disapproved of this activist and highly instrumental view of common law adjudication, but he is convinced that by 1820 this view had carried the day. By that time, Horwitz declares, American judges had come "to think of the common law as equally responsible with legislation for governing society and promoting socially desirable conduct." "11

Having sketched the transformation of the jurisprudence that underlay the common law, Horwitz seeks to show how the new, instrumental vision of law was employed by the ante bellum judiciary to effect major changes in virtually all substantive areas of the common law and in the legal system. Changes in property, contract, and commercial law merit special attention in Horwitz's analysis.

Property, wrote Blackstone, is "that sole and despotic dommation which one man claims and exercises over the external things of the world, in total exclusion of the right of any other individual in the universe." 12 This absolutist notion of property, reflected also in the common law maxim, sic utere tuo ut alienum non laedas, ${ }^{13}$ proved unsuitable for a society seized with the spirit of economic development. Thus, it was gradually abandoned and replaced by a inuch more relative, nore utilitarian concept of property and of property rights. Under the new conception landed property became, in Horwitz's opimion, but another "instrumental value in the service of the paramount goal of

10. Id. Although Horwitz, in an earlier article, The Emergence of an Instrumental Conception of Law, 1780-1829, 5 PERSPECTIVEs IN AMERICAN HISTORY 287 (1971), was the first scliolar to use the term "instrumental" to describe the conception of law that prevailed in this era, essentially the same notion can be found developed in K. Llewelyn, The Common LaW TRadition: DecidING APPEALS (1960). An interesting explanation for the decline of "instrumentalism" is offered in Nelson, The Impact of the Antislavery Movement Upon Styles of Judicial Reasoning in Nineteenth Century America, 87 HaRv. L. Rev. 513 (1974).

11. M. HoRwITZ, supra note 1 , at 30 .

12. $2 \mathrm{~W}$. Blackstone, Commentaries * 2 .

13. Use your own [property] so as not to liarm another's. 
promoting economic growth."14

Horwitz finds the new view of property adunbrated in several early nineteenth-century cases involving water rights. Typical was the 1805 New York case of Palmer $v$. Mulligan, ${ }^{15}$ in which the court, dispensing with the ancient coinmon law "natural flow" doctrine, held that an upper riparian landowner could diminish the flow of water to a downstream millowner for mill purposes if the public benefit exceeded the resulting private harm. The old common law notion, the judge opined, "must be restrained within reasonable bounds so as not to deprive a inan of the enjoyment of his property." "16 This conscious weighing of costs and benefits was as unprecedented as the emphasis on the inuplied right to develop the property. The court found this right to be a main characteristic of land ownership. Horwitz acknowledges that the new conception of water rights did meet with opposition, and he notes that throughout the first quarter of the nineteentli century numerous cases can be found which affirm the traditional common law approach to water rights conflicts. He argues, however, that by the coming of the Civil War a balancing-of-uses approach had clearly triuinphed. ${ }^{17}$

The Mill Acts represented an even further erosion of longstanding common law notions of property rights. These acts, which provided for the payinent of yearly damages to a landowner whose property had been flooded by the erection of a mill on adjoining land, had existed in most jurisdictions smce the eighteenth century. However, they did not become important until the nineteenth century when courts, especially in Massachusetts, interpreted them to provide the exclusive remedy for flooded propertyholders. By judicial decision, therefore, the damaged landowner was cut off from his common law remedies, including the common law action to abate a nuisance, and was compelled to accept the flooding of his property im exchange for the payment of statutorily determmed damages. The rationale for the Mill Acts was simple-by limiting damages and precludimg mjunctive relief they encouraged the building of mills and the development of water-powered mdustry. The passage of the Mill Acts, or perhaps more accurately, the gloss put on these statutes by nineteenth-century magistrates, signaled a clear break with the old order that had looked upon the flooding of land as a fundamental violation of property rights not to be justified under any circumstances.

Horwitz finds other evidence of a retreat from absolutist notions of

\footnotetext{
14. M. HoRwitz, supra note 1 , at 53 .

15. 3 Cai. R. 307, 313-14 (1805).

16. M. HoRwiTZ, supra note 1 , at 37 .

17. Id. at 40 .
} 
property rights in developments during the same period in the law of waste and nuisance. Under well-established English common law principles any alteration by a tenant of leased land rendered the tenant liable to his landlord for waste. Horwitz argues that such a strict rule was incompatible with the needs of a young and growimg nation that wished to encourage, rather than penalize, the clearing and development of vast tracts of wild and uncultivated forest lands. By the second quarter of the nineteenth century therefore, most American courts had either modified or abandoned the strict English rule, adopting in its stead the rule that alterations in land compatible with good husbandry sliould not be deemed waste. ${ }^{18}$ Horwitz detects a similar, albeit slower and more subtle, evolution away from strictness and toward greater flexibility in the law of nuisance. A corollary to the right of exclusive dominion-the essence of the English common law of property-was the right to stop activities outside one's land that imterfered with the enjoyment of one's own land. Under the traditional rule, even lawfully and nonneghigently conducted activities could be enjomed as nuisances.

Up to the time of the Civil War American judges continued to affirm the traditional doctrine, but beneath the surface of their opinions, Horwitz argues, the doctrine was being undermined. The old common law distimction between private and public nuisances was seized on and the notion of public nuisance was expanded to prevent individual property owners from blocking large works of internal improvement. Simce these works affected more than a single landowner, under the newly developed theory they were viewed as public nuisances, not subject to private legal attack. At the same time, courts began to extend total immunity from nuisance suits to private companies that were actimg pursuant to legislative charters. These companies were to be held only to the standard of due care, embodied in the then rapidly developmg American law of negligence, and not to the standard of strict liability incorporated in the older form of nuisance law. ${ }^{19}$ "After 1840," Horwitz asserts, "the principle that one could not be held liable for socially useful activity exercised with due care became a commonplace of American law."20 The net result of all these changes in the law of property, Horwitz argues, was that by 1860 the conception of property liad been transformed "froin the eighteenth century view that dominion over land above all conferred the power to prevent others fronı interfering with one's quiet enjoyment . . . to the nineteenth century assumption that the essential attribute of property ownership was

\footnotetext{
18. Id. at 54-55.

19. Id. at 74-99.

20. Id. at 99 .
} 
the power to develop one's property regardless of the injurious consequences to others."21

Horwitz seeks to show that equally dramatic changes were taking place in the law of contracts. Most important of these changes, in his view, was the gradual disappearance of the equitable theory of contract and the einergence of the will theory of contract. Since the Middle Ages, the English common law, insofar as it recognized contract law at all, ${ }^{22}$ insisted that the substantive fairness of contractual bargains could be looked into as a prerequisite to their enforcement. Courts of equity thus consistently refused to order the specific performance of contractual obligations where they found grossly unequal bargaining power or inadequate consideration. Horwitz illustrates this insistence on the substantive fairness of exchanges by quoting a reinark made by South Carolina's Chancellor Desaussure in 1817: "It would be a great inischief to the community, and a reproach to the justice of the country, if contracts of very great inequahity. . . could not be examined into, and set aside." "23

This view of the proper judicial rule had come under attack as early as 1790, Horwitz notes, in the first English treatise on the law of contracts, Powell's Essay Upon the Law of Contracts and Agreements. Powell argued that courts had no business looking into the substantive fairness of exchanges or trying to rewrite contracts for the parties. Rather, their job was simply to determine whether there had been a ineeting of mimds; therefore, courts should enforce all contracts freely entered into. " $[\mathrm{A}]$ man is obliged in conscience to perform a contract which he has entered into, although it be a hard one," Powell wrote. ${ }^{24}$ Horwitz proposes that such arguments were warmly received in the new American states at a time when the development of an extensive inarket economy together with wildly fluctuating prices was helping to erode notions of objective value and just price. The notion that the value of consideration was subjective and better determined by the contracting parties than by the court was gaining popular acceptance. According to this view, which had triumphed in American courts by the mid-nineteenth century, the purpose of contract law was "not to assure the equity of agreements but simply to enforce . . . those willed transactions that parties to a contract believed to be to their mutual

21. Id. This conclusion is a bit of an exaggeration since, as Horwitz recognizes, even in those jurisdictions which had completely abandoned the nuisance doctrine liability was still imposed for negligently conducted activities on one's own land. Id. at 97-99.

22. Until the nineteenth century, according to Horwitz, contracts were considered a relatively unimportant area of common law, and were mainly seen as a means of transferring title to property. Id. at 162-63.

23. Id at 164-65.

24. Id. at 160-61. 
advantage."25

The triumph of the will theory of contract meant that ancient common law rules, including those that were intended to protect the weaker segments of society against those with greater bargaining power, could be abrogated by private agreement. Horwitz finds examples of such abrogation in the evolution of the view that workers who entered into contracts for a certain price, to be paid at the end of a term, could not recover for the value of the services performed to date if they left before the end of the term. The hiteral terms of the express contract prevailed over any theory of quantum meruit. ${ }^{26}$ Another example is seen in the emergence of the rule that common carriers could contract out of their traditionally strict hability for the safe transit of goods and passengers. Sonetimes, the mere giving of notice to the public restricting their liability was considered sufficient to abrogate the old rule. ${ }^{27}$

The developinent of the will theory of contract was instrumental, Horwitz believes, in causing some of the changes that took place in commercial law during this same period. In insurance law, for example, through the first quarter of the nineteenth century the dominant view had been that it would be against public policy to allow individuals to insure agamst losses arising from their own neghigence. Such a rule seemed increasingly archaic as the economy of the United States developed. By 1830, in part under the influence of the will theory stipulating that public duties could be modified or suspended by private agreement, courts were regularly holding that contracts of indemnification for losses caused by the neghigence of the insured were valid and enforceable. ${ }^{28}$

Horwitz demonstrates that the whole field of insurance law was undergoing a fundaniental transformation at this time. During the eighteenth century, in England and in America, insurance contracts were seen as private arrangements entered into between merchants essentially for mutual convenience rather than for profit. The paradigmatic agreement, the contract of marine insurance, rested on personal relations between members of the same profession. These agreenients incorporated a high standard of disclosure and of conduct on the part of the insured, thus refiecting the moralistic concepts of the prevailing insurance law. As early as 1790, however, commercial enterprises specializing in insurance began to appear in the United States, and insur-

25. Id. at 181 .

26. Id. at 186. For another view of this type of employment contract, see R. PosNeR, EcoNOMIC ANALYSIS OF LAW 184 (1977), in which the author contends that the withholding of payment until the end of the term was the only practical device at the time for assuring that the employee would complete the agreed-upon work.

27. M. HoRwITZ, supra note 1 , at 204-07.

28. Id. at 202-03. 
ance law began to reflect these new realities. The courts gradually accepted what Horwitz calls "an actuarial conception of social risk," 29 recognizing that insurers could factor the known risks of the insured undertaking into their calculations when premiums were set. Consequently, a inore impersonal, less inoralistic standard could be applied in judging disputes between insured merchants and their insurers. ${ }^{30}$

In his discourse on commercial law Horwitz attacies special importance to the role played by the judiciary in the early nineteenth century im the developinent of a modern law of negotiable instruments. Promissory notes were almost equivalent to currency in England after an Englisli statute of 1704 had established their negotiability. But, by 1800 , only five American states had adopted the principle of full negotiability. ${ }^{31}$ In the majority of American jurisdictions there were severe limitations on the assignment of notes; moreover, there was no recognition of the right of reinote endorsees to cut off the defenses of the original inaker, which, as Horwitz points out, is the essence of full negotiability. ${ }^{32}$ It was feared that allowing the unfettered assignment of promissory mstruments would encourage hitigation and, in particular, might pernnit the powerful to harass small property owners witl vexatious lawsuits based on fraudulent land titles or otherwise to oppress the noncommercial classes. ${ }^{33}$ In this, as in so many other areas of law, there was, Horwitz believes, a noral dimension to the opposition to inodernization. The judiciary, however, understood how important the estabhshment of the principle of negotiability was to the expansion of commerce. Horwitz details how state courts in Massachusetts and New York, among others, used their judicial powers to estabhisl or to broaden the negotiability principle. ${ }^{34}$ An even more hospitable attitude, Horwitz deinonstrates, was to be found in the federal courts which in a series of decisions expanded the concept of negotiability. The federal trend culminated in Swift $v$. Tyson, ${ }^{35}$ which confirmed the right of a holder in due course to collect on a note before its maturity date even though the original transaction on which the note was based was without legal validity. ${ }^{36}$

Morton Horwitz has succeeded im compiling an extraordmary ainount of data documenting the development of the American common law in the ante bellum era. He gives a rich and detailed account

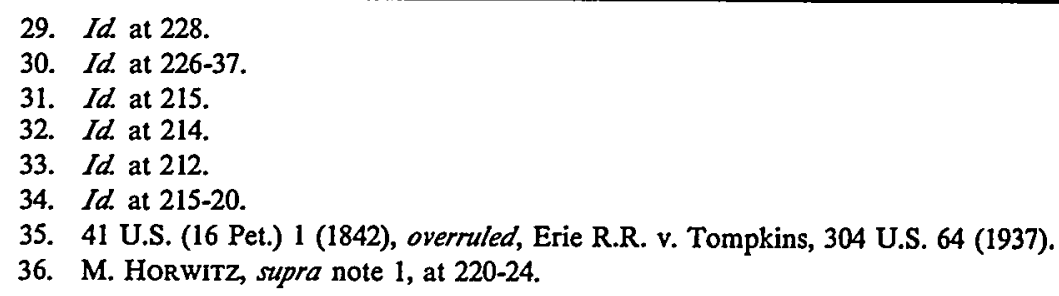


of the many legal developments that occurred during that period. The account, though it may be flawed by an occasional technical blemish, is, I think, on the whole a very accurate one. The book, however, cannot be evaluated merely on those terms. It purports not only to give us a narrative description of the changes that occurred in the law but also to provide an intellectual framework for understanding why things happened as they did. It is on these terms, the author's own, that the work must be judged.

A close examination of the Horwitz thesis on the transfornation of American law reveals two central arguments. First, he contends that a deliberate choice was made and implemented by the rising commercial classes and their allies in the legal profession to eschew the tax system in favor of the legal systein as a neans of promoting the economic development of the new American nation. Second, Horwitz argues that the changes wrought in the legal order had negative consequences for the equitable distribution of society's wealth and power.

The fundamental question raised by the first argument, Horwitz asserts, is "why there developed so clear a pattern of subsidization [of economic growth during this period] through the use not of the tax system but of the legal system." 37 One explanation, he argues, seems fairly clear. Those who held the levers of power understood that "[c]hange brought about through technical legal doctrine can more easily disguise underlying political choices." 38 Or, put another way, what might be difficult and dangerous to try to accomplish through the legislature could be accoinplished safely, almost imvisibly, through the courts. The direct promotion of economic growth by legislative subsidy and taxation raised the possibility of political conflict-voices miglit be raised in the popularly elected legislatures against the passing out of benefits to "special interests." Furthernore, economic subsidy through taxation might illustrate taxation's potential for wealth redistributionsomething the moneyed classes wanted to avoid at all costs. Fimally, there was the very selfish consideration by the decisionmakers that since the property tax was the major form of taxation, promotion of growth through taxation would put the burden of development principally on the property-owning classes. Indirect promotion of economic growth through changes in the common law was an infinitely better option in the eyes of the possessing classes simce, according to Horwitz, it would achieve the objective of economic development with no attendant risks. ${ }^{39}$

The Horwitz thesis is therefore one that posits orcliestrated and

37. Id. at 100 .

38. Id. at 100-01.

39. Id. 
purposive legal change. As he puts it, "[a]s pohtical and economic power shifted to merchant and entrepreneurial groups in the postrevolutionary period, they began to forge an alliance with the legal profession to advance their own interests through a transformation of the legal system."40 Horwitz inaintains that by 1850 this alliance had largely accomphished the intended revolution in legal values. By that date, he contends, "[a]nticommercial legal doctrines had been destroyed or undermined . . . . Legal relations that had once been conceived of as deriving froin natural law or custoin were mcreasingly subordinated to the disproportionate economic power of individuals or corporations . . .."41

The case that Horwitz advances to support his theory of conscious, purposive legal change does not strike me as convincing. The evidence consists almost entirely of Horwitz's reading of a large number of the judicial opinions of the era and his extrapolation from those opinions of a pattern of judicial inotivation. Horwitz seems to be arguing that a pattern is apparent in the common law decisions of the postrevolutionary era, and that the most coinpelling explanation for this pattern is that a conscious choice was made by the judiciary to transform the law in a certain direction. It seems a very slender reed on which to rest so large a thesis. If the coinbination (one is almost tempted to say conspiracy) that Horwitz posits existed-a combimation of judges, lawyers, and inerchants-and if the parties to the combination had in fact made a deliberate choice to work far-reaching changes in the law, then surely one would expect to find some external evidence for the scheme. Presumably diaries could be quoted, correspondence adduced, and pubhished articles cited that would show that the entrepreneurial classes and their allies in the legal profession had reflected on options for econoinic development, determined which option seemed least hazardous to their interests, and then deliberately implemented their plans. Horwitz, however, supplies virtually no evidence that there was any such theorizing about alternative strategies of economic development at the tine. There is also virtually no evidence that the leading statesmen of that era were reflecting on the imphications for wealth and power distribution of each alternative economic strategy. At best, only sketchy evidence is presented that the common law judges were aware of whose econoinic interests were being furthered and whose interests disadvan-

40. Id. at 253 (einphasis added). Horwitz at times hedges on this point of deliberate, conscious action, suggesting instead that the principal legal actors were not aware of what they were doing or of whose interests they were serving, but rather were acting in an ad hoc way and responding to forces beyond their coinprehension. See, e.g., id. at 34 . This notion is never really developed, however. Besides, the theme of conscious, deliberate choice is too constantly invoked to be taken as anything other than the essential message of the book.

41. Id. at 253. 
taged by their decisions. To be sure, an occasional hint of such awareness is uncovered. Horwitz does, for example, cite a letter by Joseph Story, written shortly after the decision in De Lovio v. Boit. ${ }^{42}$ In that case, federal admiralty jurisdiction was extended to marine insurance cases, thus taking those cases out of the hands of juries. In his letter Story notes with satisfaction that the decision was popular among the merchants in Boston, none of whom cared for the large verdicts that juries were awarding in insurance cases..$^{43}$ But beyond this, the work is surprismgly devoid of a systematic effort to examine the legal consciousness of the era through the nonjudicial writings of the principal legal actors. Historians will surely find it remarkable that a work premised on the central theine of inotivation should reflect so little effort to mine the materials in which presumably some of the best evidence of motivation could be found.

Illustrative of the general weakness inherent in Horwitz's method of argument, it seems to me, is his handling of Justice Story's opinion in the landmark case of Swift v. Tyson. ${ }^{44} \mathrm{He}$ devotes considerable space to discussion of this case, treatimg it, im a sense, as the prototypical expression of the judicial consciousness of the age. Horwitz argues that Story's evocation of "general principles of commercial law" is completely at odds with the Justice's inature legal theory as evidenced im his massive 1834 treatise on Conflict of Laws. That treatise, notes Horwitz, took a very positivist view of law and seemed to entirely reject all notions of an intrinsically just natural law. ${ }^{45}$ How can one then explain the recrudescence in Swift of the general principles of cominercial jurisprudence? Horwitz posits a nonjurisprudential explanation. ${ }^{46}$ $\mathrm{He}$ argues that the legal theory espoused in $S$ wift is simply incapable of being reconciled with the jurisprudence enbodied in the treatise. The theory can only be understood as a rhetorical device used by Story to cover what was essentially an "attempt to inipose a procommercial national legal order on unwilling state courts." 47

The evidence offered by Horwitz for this theory consists entirely of a comparative analysis of the conflicts treatise, the Swift opmion, and

42. 7 F. Cas. 418 (C.C.D. Mass. 1815).

43. Such a decision could only have been popular among Boston's merchant-underwriters, since the merchant-shipowners stood to lose by it. M. HoRwIrz, supra note 1, at 141. In a later passage Horwitz acknowledges that some segments of the mercantile community might not have been so pleased with the decision. See id. at 251.

44. 41 U.S. (16 Pet.) 1 (1842), overruled, Erie R.R. v. Tompkins, 304 U.S. 64 (1937). Swift held that in diversity cases involving contracts and other instruments of a commercial nature federal courts were bound to apply only the statutory law of the states in which they sat and not the state's case law. See M. HoRwirz, supra note 1, at 245.

45. M. HoRwiTz, supra note 1, at 248.

46. Id. at 249.

47. Id. at 250 . 
an opinion by Story in the circuit court case of De Lovio v. Boit. Unfortunately, no corroborative evidence is advanced to support the case for Story's insincerity. It is possible, after all, to cite other passages from Story's published legal writings that suggest that his allusion in Swift to general principles of law inay not have been so inconsistent. He did, for exainple, in his 1835 treatise on Equity Jurisprudence, evidence some sympathy for the notion that there might be more to the law than the language of statutes and cases. ${ }^{48}$ More important, im a case decided the year before Swift involving the fate of a group of Africans who had seized control of their slave ship and steered it to a United States port, Story had relied on "eternal principles of justice" in resolvimg "[t]he conflict of riglits between the parties." 49 This is not to suggest that these passages prove that Justice Story did in fact believe in universal legal principles. However, it seems to me that they do at least cast a shadow of doubt on Horwitz's accusations of insincerity and pure instrumentalisin, further highlighting the need for additional evidence to determine the motivations underpinning Justice Story's opmions.

The Transformation of American Law is also surprismgly free of effort to docuinent precisely what the redistributive consequences were of the changes in the law that it describes. Yet, the book very openly argues that a inajor redistribution of wealth and power in the society occurred and was intended. Horwitz states that the decision to promote growth through the legal, rather than the tax, system reflected a decision about "who would bear the burdens of econoinic growth"50 and who would reap the benefits. Elsewhere he declares:

If the sole criterion of the public interest is the maximization of economic growth, a case can be made for the fact that the American legal system after the Revolution was transformed successfully to promote developmental goals. But if we look at the resulting distribution of economic wealth and power - at the legal expropriation of wealth or at the forced subsidies to growth coerced from the victims of the process-it is difficult to characterize it as codifying some consensus on the objective

48. 1 J. StORY, EQuity JURISPRUdence 34 (2d ed. 1839). Commenting on the views of foreigners who believed that law courts were limited to construing technical rules while equity courts alone were allowed to concern themselves with justice, Justice Story wrote:

Such persons seem to labor under the false notion, that courts of law can never administer justice with reference to principles of universal or natural justice . . . . Now, such a notion is founded in the grossest mistake of our systems of jurisprudence. Courts of Common Law, in a great variety of cases, adopt the most enlarged and liberal principles of decision. . . . This is especially true, in regard to cases involving the application of the law of nations, and of commercial and maritime law and usages . . . .

49. Umited States v. Libellants and Claimants of the Schooner Amistad, 40 U.S. (15 Pet.) 518,595 (1841).

50. M. HoRwITz, supra note 1 , at 101. 
needs of the society. ${ }^{51}$

Curiously, the book never does systematically examine "the resulting distribution of economic wealth and power." No inatter what area of law is being discussed, the book conveys the impression that legal change was working to the advantage of the rich and to the disadvantage of society's poorer segments, but the argument is almost always impressionistic. There is little discussion of the actual distribution of wealth in the ante bellum era or of the maumer in whicls this distribution was affected by the strategy of economic developinent that, according to Horwitz, was opted for. In final analysis, this thesis, as well as Horwitz's argument concerning judicial motivation, remams little more than an educated surmise. Strangely, the autlior comes close to conceding this point in a passage whose tentativeness contrasts sharply with the self-confident tone of nost of the book's assertions:

Until we know much more about the potential redistributive effects of state tax systems in this period, it would be dangerous to make any firm comparisons. Nevertheless, it does seem fairly clear that the tendency of subsidy through legal change during the period was dramatically to throw the burden of economic development on the weakest and least active elements in the population. By contrast, it seems plausible to suppose that in a period when the property tax provided the major share of potential state revenue, the burdens of subsidy through taxation would have fallen disproportionately on the wealthier segments of the population. ${ }^{52}$

The work is also notably lacking in systematic analysis of the social structure of the period covered. There is, for example, no real delimeation of the classes and groups whose imterests were involved. Indeed, the book, while nuanced and subtle in its handlimg of the evolution of the substantive law, is ratler heavyhanded in its treatment of social organization. Vague terms like "the commercial classes" or "the bar" abound and are often used in an undifferentiated way to depict congeries of highly divergent and competitive imterest groups. The use of such broad categories allows Horwitz to make sweeping statements about the thrust and direction of legal change but presents a distorted picture of the precise impact of particular shifts im legal doctrime upon various social groups. Thus, some of the social antagomsms that Horwitz portrays as conflicts between mercantile interests and the rest of society ${ }^{33}$ would seem to be more appropriately described as conflicts withm the inerchant and entrepreneurial classes.

51. Id. at xvi (emphasis added).

52. Id. at 101 (emphasis added).

53. The author occasionally acknowledges the fact of intramural conflict within the merchant classes but fails to develop the notion or to explore its implications for his thesis. See, e.g., id. at 251. 
A related weakness is the work's failure to explore the political background against which changes in the law were taking place and to integrate the legal and political changes. Such exploration seens to be required by the book's main theme. The argunent, after all, is that the law was being altered by the common law judges to further the interests of merchants and businessmen. Yet, inany of these changes were occurring against the background of rising poputisin and Jacksonian democracy. An obvious question is presented by this development: Why didn't the more popularly responsive state legislatures simply overrule the decisions of the common law courts if these decisions were so favorable to the special interests and so prejudicial to the general public? As one reviewer very sympathetic to Horwitz's interpretation noted, the proposition that the commercial interests were able to triumph in an age of democratic political ascendancy is historically curious. $^{54}$

One detects in Morton Horwitz's book a kind of nostalgia for the distant past. Implicit in inuch of what he writes is the notion that the preinodern legal order was a just one, or certainly more just than the order which replaced it. If one accepts this assumption, the transformation in American law that he describes can only be viewed with dismay. But such an assumption seems dubious at best. Surely the old common law contained inuch that was unjust and much more that was simply archaic. Its paternalism inay have offered a measure of protection to the laboring classes, but the paternahism came with a heavy price, as it was premised on a social order of rigid hierarchy and extremely limited inobility. Moreover, the class which created the cominon law and was most protected by it was the class at the top of the hierarchy-the Enghish landed aristocracy.

Left unchanged, the old legal order represented at the very least a large obstacle to economic development in the new American nation, and even Horwitz does not contest the proposition that the developinent of the American econoiny was a goal that deserved to be promoted. Seen from this perspective, nuany of the changes in the common law described by Horwitz-the dethroneinent of English case authority, the adoption of a balancing-of-mterests approach to land disputes and concomitant abandonment of absolutist notions of property rights, the developinent of a new law of waste, the niodernization of the law of insurance, to cite a few examples-seem salutary. Rather than constitutimg evidence of a conspiracy to gut the law of its humane core, these changes appear to reflect the legal order's responsiveness to changed social conditions and its ability to evolve $m$ the direction of

54. Genovese, Book Review, 91 HaRv. L. Rev. 726, 735 (1978). 
greater flexibility, greater maturity, and, indeed, greater plain common sense. ${ }^{55}$ There inay be a less benign explanation for what was happening to the American common law in the period 1780-1860. Few, however, will be convinced of the validity of such an alternate explanation absent the production of inore and better evidence than that provided in the pages of The Transformation of American Law.

55. For a somewhat similar interpretation, see P. NONEr \& P. SELZNICK, LAw AND SocIETY IN TRANSITION: TOWARd Responsive Law 84 n.18 (1978). The authors state:

The evidence suggests that in matters of property, contract, and torts the courts of that time felt able to bend or discard the narrow rules of earher precedents that were found incongruent with a commonsense understanding of proper business conduet .... A long series of such small practical adaptations over a long period resulted in transforming a private law suited to the practical needs of a stable agrarian economy into one more suited to the practical needs of an expanding commercial and industrial economy. The authors, however, stress the courts' and the law's passive adaptabihity. 